\title{
Management of citrus canker in Kagzi lime under nursery condition using Biorationals
}

\author{
K. CHETHANKUMAR*, K.C. KIRANKUMAR AND R. K. MESTA \\ Department of Plant Pathology, University of Horticultural Sciences, BAGALKOT (KARNATAKA) INDIA
}

\section{ARITCLE INFO}

Received : 03.04 .2017

Revised : 18.08 .2017

Accepted : 30.08 .2017

\section{KEY WORDS :}

Xanthomonas citri subsp citri, Garcinia indica, Lysinibacillus xylanilyticus

*Corresponding author:

Email : chethankumarseri@gmail.com

\begin{abstract}
:
The present study was carried out by using different bioagents and botanicals for management of citrus canker on four months old kagzi lime seedlings, Among the different botanicals treated, Garcinia indica fruit rind extract was found be effective in management of citrus canker under nursery condition by reducing the per cent leaves infection $(81.55 \%)$, number of shoots infected $(73.24 \%)$ and per cent leaf area infection $(82.63 \%)$. This was followed by bioagent treatment consisting of soil and aerial application of Lysinibacillus xylanilyticus (VK-6B), which recorded 77.11 per cent, 71.43 per cent and 80.70 per cent, respectively.
\end{abstract}

How to view point the article : Chethankumar, K., Kirankumar, K.C. and Mesta, R. K. (2017). Management of citrus canker in Kagzi lime under nursery condition using Biorationals. Internat. J. Plant Protec., 10(2) : 324-328, DOI : 10.15740/HAS/IJPP/10.2/324-328. 